Collection/Special Issue: COST Action FP1202

"Strengthening conservation: a key issue for adaptation of marginal/peripheral populations of forest trees to climate change in Europe (MaP-FGR)"

Guest Editors: Fulvio Ducci, Kevin Donnelly

\title{
Comparison of genetic parameters between optimal and marginal populations of oriental sweet gum on adaptive traits
}

Murat Alan

\section{Introduction}

Oriental sweet gum (Liquidambar orientalis Mill.) is a relic and endemic species of Turkey. The natural distribution area of the species is only 3,200 hectares between 0 1000 meters in elevation in southwest Turkey. Adult trees with breast height diameter more than $20 \mathrm{~cm}$ are usually wounded repeatedly to produce valuable balsam

$\square$ Karabuk University, Faculty of Forestry, Karabuk (Turkey)

@ Murat Alan (muratalan@yahoo.com)

Received: Apr 04, 2017 - Accepted: May 15, 2018

Citation: Alan M (2018). Comparison of genetic parameters between optimal and marginal populations of oriental sweet gum on adaptive traits. iForest 11: 510-516. - doi: 10.3832/ifor2450-011 [online 2018-07-18]

Communicated by: Fulvio Ducci

Genetic parameters of 9 oriental sweetgum (Liquidambar orientalis Mill.) populations were estimated at a common garden test. Open-pollinated seeds were collected from 16-27 families for each population. The common garden test was established in 2009 using a randomized complete block design in 25 blocks with single tree plot, with each block included 223 families. Breast height diameter, height and crown diameter were measured at the age of five. The purpose of study was to compare the genetic parameters of optimal and marginal populations and to assess the findings for genetic conservation. The study revealed significant variability in all traits evaluated. In variance components, variation among populations was three times higher than that of families. Individual heritability estimates for breast height diameter, height and crown diameter pooled across the whole dataset (marginal and optimal populations) were $0.21 \pm 0.04,0.27 \pm 0.04$ and $0.11 \pm 0.03$ and additive genetic coefficients of variation were $13.4 \%, 9.1 \%$ and $7.1 \%$, respectively. Individual heritability estimates for breast height diameter, height and crown diameter in marginal and optimal populations were $0.27 \pm 0.10,0.19 \pm 0.08$ and $019 \pm$ 0.08 and $0.19 \pm 0.04,0.29 \pm 0.05$ and $0.09 \pm 0.03$, respectively. Additive genetic coefficients of variation for breast height diameter, height and crown diameter were $16.7 \%, 8.3 \%$ and $10.8 \%$ in marginal and $12.8 \%, 9.1 \%$ and $6.2 \%$ in optimal populations, respectively. While breast height diameter and crown diameter were more heritable for marginal populations, height was more heritable for optimal populations. These findings are discussed in terms of genetic conservation of oriental sweet gum.

Keywords: Liquidambar orientalis, Genetic Variation, Individual Heritability, Gene Conservation, Climate Change

(Topcuoglu 1968). Since almost all trees have been continuously injured to produce balsam, fact that may be result to their dead, the species is at the risk of extinction. Therefore, it was identified as a priority species for conservation and a technical guideline for its conservation and use was prepared by the European Forest Genetic Resource Programme (EUFORGEN - Alan \& Kaya 2003).

Oriental sweet gum is an economically important species, due to the natural balsam producing ability which is exceptional among forest trees. Sweet gum oil is used in pharmaceutical, chemical, and cosmetic sectors. It is a raw material for in the production of cinnamyl alcohol and acid and it is used as a stabilizer for soap and cosmetic products. Almost all of the produced oil is exported (Alan \& Kaya 2003). Due to over exploitation, oil production has dramatically declined from 180 tons in 1950 to 1,113 $\mathrm{kg}$ in 2013 (Velioglu et al. 2008, OGM 2015).

The natural distribution area of oriental sweet gum comprises of areas with very productive deep soil and of riparian lowland habitats; areas that attract interest for farming. For this reason, a great portion of the oriental sweet gum lands has been illegally transformed in agricultural fields. Due to habitat loss by deforestation and drainage of lowland of the Aegean Region, the natural distribution area of the oriental sweet gum has been decreased from 7,000 ha to 3,200 ha since 1947 (Alan \& Kaya 2003).

Knowledge on the existing genetic variation within and between populations is essential for the species management, its domestication and the application of breeding and conservation strategies (Black-Samuelsson et al. 2003, Munthali et al. 2012). The molecular markers and the common garden tests are two powerful tools applied for the characterization of genetic variation in forest tree populations. While genetic markers are beneficial to convey genetic drift, gene migration and mating system, common garden tests are the ones providing information for quantitative traits and more explanatory for defining adaptive variations (Eriksson et al. 2003, White et al. 2007).

Recently, a comprehensive genetic diver- 


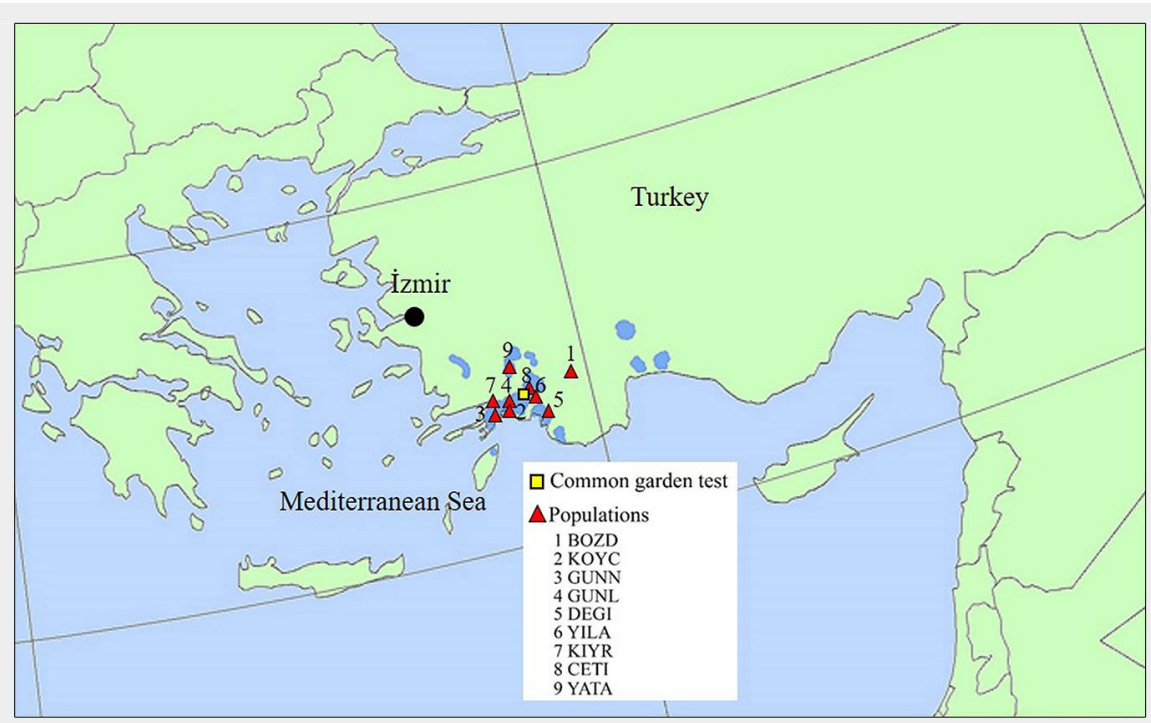

Fig. 1 - Location of the nine populations of Oriental sweet gum analyzed and of the common garden test. Base map from EUFORGEN (2016).

sity research project has been conducted with oriental sweet gum by using molecular markers. For this purpose, 18 populations were studied covering the whole distribution area of oriental sweet gum (Velioglu et al. 2008). The results revealed that the difference among populations was high and the gene flow among populations was low. Such a result was not surprising, because the populations were often separated or disconnected. Velioglu et al. (2008), recommended that 9 out of the 18 populations should be conserved as ex situ genetic resources. Then, a common garden test was established in 2009 with those 9 populations suggested for ex situ conservation. Many researches using molecular markers have already been carried on (Or 2007, Ozdilek 2007, Albayrak \& Arican 2009, Kaya et al. 2008, Ozdilek et al. 2012). Except for Albayrak \& Arican (2009), researchers studied the whole 18 populations using molecular markers, finding divergences and similarities of populations, and recommending some populations for in situ or ex situ genetic conservation. Albayrak \& Arican (2009) found also similarities and divergences among five populations. Despite such many molecular investigations, there has been no studies on quantitative traits of oriental sweet gum. Indeed, the best way to test for genetic differences among populations within a species is to conduct common garden experiments ( Rehfeldt et al. 2002). Information from common garden test may improve our understanding of local adaptations to environmental factors, as well as our predictions regarding the impact of climate change on tree fitness and community composition (Vitasse et al. 2009).

Species are expected to have highest abundance at the core areas of their distribution, with smaller and more disjunct populations found at the margins of distri- bution (Brussard 1984). Understanding the genetic characteristics of plant populations at the margins of a species' natural range is important because the peripheral populations are likely to preserve their adaptive and evolutionary potential under the anticipated global climate change conditions (Lesica \& Allendorf 1995, Aitken et al. 2008, Eckert et al. 2008, Pandey \& Rajora 2012). Whether geographically central populations differ in their genetic diversity and differentiation levels from their marginal counterparts remains an open question. However, reviews of empirical studies have reported contradictory results on the patterns of distribution of genetic variation in marginal vs. central populations (Brussard 1984, Lesica \& Allendorf 1995, Gaston 2003, Vakkari et al. 2009). Eckert et al. (2008) reviewed 134 studies, representing 115 species, that used molecular and biochemical genetic markers, and found that in most cases, the difference in genetic diversity between central and peripheral population was not large. Molecular studies that related optimal and marginal population were abundant as mentioned above, though studies based on quantitative traits were limited (Rose et al. 2009, Kreyling et al. 2014) and not directly focused on differences between optimal and marginal populations (Richter et al. 2012). Oriental sweet gum is a vulnerable species, therefore, in addition to molecular studies, information on quantitative traits of marginal and optimal population is fundamental for its short and long term genetic conservation.

In this study, 5-year-old seedlings from 9 different populations of Liquidambar orientalis were measured in a common garden experiment and evaluated with the aim of: (a) comparing some genetic parameters between marginal and optimal populations; (b) assessing the implications for conservation of oriental sweet gum.

\section{Materials and methods}

\section{Genetic material and experimental design}

Nine populations were used in the common garden test, as recommended by Velioglu et al. (2008). BOZD population is located at the highest altitude, while YATA is the northernmost population; other populations are mostly situated at the center of the species' distribution area (Fig. 1).

Wind-pollinated seeds were previously collected from mother trees from natural populations, with a minimum horizontal distance of $100 \mathrm{~m}$ between sampled trees in each population and a maximum elevation difference of $300 \mathrm{~m}$. Sampled trees were either located in stands, where oriental sweet gum is the dominant species, or scattered along the creeks in riparian stands, where the above minimum elevation difference criterion was sometimes disregarded due to the narrow elevation zone. The mean altitude of the sampled sites ranged among 5 and 1,100 $\mathrm{m}$ a.s.l. (Tab. 1).

All seeds were collected and kept separately in plastic bags for each mother tree and the bags were labelled. The number of families and the number of seedlings obtained for each population ranged from 16 to 27 and from 349 to 601 , respectively.

Sowing of seeds was carried out in the Gokova Nursery of Mugla Province, Turkey in the spring of 2008. ENSO pots (Finland type) of $259 \mathrm{~cm}^{3}$ with 45 seedling capacities were used. Seedlings were grown under common conditions and were transplanted in the common garden test site in March 2009.

The experiment test site was located within the optimal distribution area of oriental sweet gum in Turkey $\left(37^{\circ} 00^{\prime} 18^{\prime \prime} \mathrm{N}\right.$ latitude, $28^{\circ} 30^{\prime} 14^{\prime \prime} \mathrm{E}$ longitude, elevation $100 \mathrm{~m}$ a.s.l. - Fig. 1). The test was established using a randomized complete block design in 25 blocks with single tree plot. Each block included 223 open pollinated (OP) families planted at a spacing of $3 \times 4$ $\mathrm{m}$. The breast height diameter $(\mathrm{mm})$, the height $(\mathrm{cm})$ and the crown diameter $(\mathrm{cm})$ of seedlings were measured at the age of five. The crown diameter of each tree was measured on two perpendicular directions and the two measurements were then averaged.

\section{Statistical analyses}

The initial height of seedlings at the time of plantation was used as covariate in the statistical model. Individual tree data were subjected to analysis of variance (ANOVA), following the statistical model below for all the traits studied (eqn. 1):

$$
Y_{i j k l}=\mu+A X_{i j k l}+b_{i}+p_{j}+f_{k(j)}+e_{i j k l}
$$

where $Y_{\mathrm{ijk}}$ is the observation on the $l^{\text {th }}$ seedling, $k^{\text {th }}$ family, $j^{\text {th }}$ population, $i^{\text {th }}$ block, $\mu$ is the overall mean, $A$ the regression coefficient, $X_{\mathrm{ijk}}$ is the establishment height of the 
seedlings ( $i j k l=1, \ldots, \approx 5000), b_{\mathrm{i}}$ is the random effect of the $i^{\text {th }}$ block $(i=1, \ldots, 25), p_{\text {j }}$ the random effect of the $j^{\text {th }}$ populations $(j=1, \ldots, 9), f_{\mathrm{k}(\mathrm{j})}(k=1, \ldots, 27)$ the random effect of the $k^{\text {th }}$ family effect within the $j^{\text {th }}$ population, and $e_{\mathrm{ijkl}}$ is the experimental error.

Variance components were estimated by using REML (Restricted Maximum Likelihood) option of the PROC VARCOMP of the software SAS ver. 9.0 (SAS Institute Inc 2002). Individual heritability, additive genetic coefficient of variation and genetic correlation were estimated by the following equations (Becker 1992, Cornelius 1994, Falconer \& Mackay 1996 - eqn. 2, eqn. 3, eqn. 4):

$$
\begin{aligned}
& h_{i}^{2}=\frac{4 \sigma_{f}^{2}}{\sigma_{f}^{2}+\sigma_{e}^{2}} \\
& C v_{g}=\frac{\sqrt{4 \sigma_{f}^{2}}}{\bar{X}} \\
& r_{A x y}=\frac{C O V_{(x, y)}}{\sqrt{\sigma_{(x)}^{2} \sigma_{(y)}^{2}}}
\end{aligned}
$$

where $h_{\mathrm{i}}^{2}$ is the individual heritability, $\sigma_{\mathrm{f}}{ }^{2}$ is the family variance, $\sigma_{\mathrm{e}}{ }^{2}$ is the error variance, $C v_{\mathrm{g}}$ is the additive genetic coefficient of variation, $\bar{X}$ is the general mean, $r_{\mathrm{Axy}}$ is the genetic correlation, $\operatorname{COV}_{(x, y)}$ is the covariance for $x$ and $y$ traits, $\sigma_{x}^{2}$ is the variance for trait $x$ and $\sigma_{y}{ }^{2}$ the variance for trait $y$. It was assumed that the open-pollinated seeds were half-sibs for the additive variance (Squillace 1974). Standard errors of individual heritability (eqn. 5) were derived from Dickerson's method suggested by Dieters et al. (1995) and the standard error of genetic correlation (eqn. 6) was derived by Falconer \& Mackay (1996), as follows:

$$
\begin{aligned}
& S E\left(h_{i}^{2}\right)=\frac{4 S E\left(\sigma_{f}{ }^{2}\right)}{\sigma_{f}{ }^{2}+\sigma_{e}{ }^{2}} \\
& S E\left(r_{A x y}\right)=\frac{1-r_{A x y}^{2}}{\sqrt{2}} \sqrt{\frac{S E\left(h_{x}^{2}\right) S E\left(h_{y}^{2}\right)}{h_{x}^{2} h_{y}^{2}}}
\end{aligned}
$$

where $S E$ is the standard error, $h_{\mathrm{x}}{ }^{2}$ is the heritability for trait $x$ and $h_{\mathrm{y}}{ }^{2}$ is the heritability for trait $y$.

\section{Results}

The highest mean of breast height diameter, height and crown diameter was found for KOYC, YILA, and YILA populations, respectively, though the lowest mean of all traits was observed for BOZD (Tab. 2). On the other hand, mean values of seedling from YATA population were also low of all traits, though higher than that observed for BOZD.

The variance components, the individual heritabilities and the additive genetic coefficient of variations for all traits of pooled data across populations are summarized in Tab. 3. The among-population variances

\begin{tabular}{|c|c|c|c|c|c|c|}
\hline Population origin & Code & $\begin{array}{l}\text { No. of } \\
\text { families }\end{array}$ & $\begin{array}{c}\text { No. of } \\
\text { seedlings }\end{array}$ & $\begin{array}{l}\text { Population } \\
\text { type }\end{array}$ & $\begin{array}{l}\text { Altitude } \\
\text { (m a.s.l.) }\end{array}$ & $\begin{array}{l}\text { Lat } \mathrm{N} \\
\text { Long } \mathrm{E}\end{array}$ \\
\hline Acipayam-Bozdag & BOZD & 16 & 349 & Stand & 1100 & $\begin{array}{l}37^{\circ} 18^{\prime} 58^{\prime \prime} \\
29^{\circ} 17^{\prime} 31^{\prime \prime}\end{array}$ \\
\hline Koycegiz- Koycegiz & KOYC & 26 & 574 & Stand & 10 & $\begin{array}{l}36^{\circ} 57^{\prime} 30^{\prime \prime} \\
28^{\circ} 42^{\prime} 09^{\prime \prime}\end{array}$ \\
\hline Marmaris-Gunnucek & GUNN & 24 & 499 & Stand & 5 & $\begin{array}{l}36^{\circ} 51^{\prime} 30^{\prime \prime} \\
28^{\circ} 17^{\prime} 38^{\prime \prime}\end{array}$ \\
\hline Fethiye-Gunlukbasi & GUNL & 27 & 601 & Stand & 5 & $\begin{array}{l}36^{\circ} 40^{\prime} 12^{\prime \prime} \\
29^{\circ} 07^{\prime} 37^{\prime \prime}\end{array}$ \\
\hline $\begin{array}{l}\text { Marmaris- } \\
\text { Degirmenyani }\end{array}$ & DEGI & 25 & 578 & Stand & 5 & $\begin{array}{l}36^{\circ} 49^{\prime} 21^{\prime \prime} \\
28^{\circ} 08^{\prime} 19^{\prime \prime}\end{array}$ \\
\hline Mugla-Yilanli & YILA & 25 & 548 & Along creek & 250 & $\begin{array}{l}37^{\circ} 02^{\prime} 27^{\prime \prime} \\
28^{\circ} 10^{\prime} 21^{\prime \prime}\end{array}$ \\
\hline Mugla-Kiyra & KIYR & 25 & 556 & Along creek & 50 & $\begin{array}{l}37^{\circ} 03^{\prime} 42^{\prime \prime} \\
28^{\circ} 32^{\prime} 47^{\prime \prime}\end{array}$ \\
\hline Marmaris-Cetibeli & CETI & 26 & 582 & Along creek & 30 & $\begin{array}{l}36^{\circ} 58^{\prime} 57^{\prime \prime} \\
28^{\circ} 17^{\prime} 38^{\prime \prime}\end{array}$ \\
\hline Mugla-Yatagan & YATA & 26 & 492 & Along creek & 250 & $\begin{array}{l}37^{\circ} 22^{\prime} 29^{\prime \prime} \\
28^{\circ} 05^{\prime} 27^{\prime \prime}\end{array}$ \\
\hline Total & - & 223 & 4779 & - & - & - \\
\hline
\end{tabular}
were about 3 times higher than the family (within-population) variances for all the traits considered in this study. The individ-
Tab. 1 - Geographical data of the studied populations.

ual heritability ranged from 0.11 (crown di- tions and among families within populaameter) to 0.27 (height). The additive ge- tions.

netic coefficient of variation was the low- The nine populations analyzed were diest for crown diameter and the highest for vided into two groups, marginal and optibreast height diameter. All factors (block, mal, according to their geographic origin. population, family) were statistically signifi- Ozdilek et al. (2012) also found that the opcant.

The analysis of variance of pooled data across populations revealed statistically significant differences both among populatimum distribution area of oriental sweet gum could be considered as the genetic diversity center and the major refugium for the oriental sweet gum. The marginal

Tab. 2 - Means ( \pm standard errors) of all traits for each population. (BHD): diameter at breast height; $(H)$ : height; $(C D)$ : crown diameter.

\begin{tabular}{llll}
\hline Populations & BHD & H & CD \\
\hline KOYC & $23.6 \pm 0.3$ & $245.9 \pm 1.9$ & $163.6 \pm 1.6$ \\
CETI & $23.2 \pm 0.3$ & $246.1 \pm 2.0$ & $165.3 \pm 1.5$ \\
YILA & $23.0 \pm 0.3$ & $250.6 \pm 2.0$ & $171.5 \pm 1.6$ \\
DEGI & $22.7 \pm 0.3$ & $248.6 \pm 2.0$ & $163.7 \pm 1.5$ \\
GUNL & $22.1 \pm 0.3$ & $243.8 \pm 1.9$ & $161.5 \pm 1.5$ \\
KIYR & $21.4 \pm 0.3$ & $235.6 \pm 2.0$ & $160.2 \pm 1.6$ \\
GUNN & $20.4 \pm 0.3$ & $237.3 \pm 2.1$ & $159.8 \pm 1.7$ \\
YATA & $18.0 \pm 0.3$ & $215.8 \pm 2.1$ & $150.7 \pm 1.7$ \\
BOZD & $15.7 \pm 0.3$ & $198.4 \pm 2.2$ & $128.4 \pm 2.1$ \\
Grand mean & $21.5 \pm 0.1$ & $237.9 \pm 0.7$ & $159.8 \pm 0.6$ \\
\hline
\end{tabular}

Tab. 3 - Variance components, expressed as percentage of the total variation, individ-

\begin{tabular}{|c|c|c|c|c|}
\hline \multirow{2}{*}{$\begin{array}{l}\text { Sources of } \\
\text { variation }^{(a)}\end{array}$} & \multirow{2}{*}{$\begin{array}{l}\text { Degrees of } \\
\text { freedom }\end{array}$} & \multicolumn{3}{|l|}{ Traits } \\
\hline & & BHD & $\mathrm{H}$ & $C D$ \\
\hline Block & 24 & $18.60^{* * *}$ & $20.09^{* * *}$ & $18.31^{* * *}$ \\
\hline Pop & 8 & $11.82^{* * *}$ & $11.92^{* * *}$ & $9.69^{* * *}$ \\
\hline Family(Pop) & 207 & $3.56^{* * *}$ & $4.60^{* * *}$ & $2.06^{* * *}$ \\
\hline Error & 4336 & 66.02 & 63.39 & 69.94 \\
\hline Total & 4767 & 100.00 & 100.00 & 100.00 \\
\hline$h_{i}^{2}$ & - & $0.21 \pm 0.03$ & $0.27 \pm 0.04$ & $0.11 \pm 0.03$ \\
\hline$C v_{\mathrm{g}}(\%)$ & - & 13.40 & 9.10 & 7.10 \\
\hline
\end{tabular}
ual heritability and additive genetic coefficient of variation for pooled data across populations. (BHD): diameter at breast height; $(\mathrm{H})$ : height; $(\mathrm{CD})$ : crown diameter; $(* * *): P<0.0001 ;(a)$ : IH (Initial height) used as covariate was statistically significant for all traits $(\mathrm{P}<0.0001)$. 
Tab. 4 - Variance components, expressed as percentage of the total variation, mean, individual heritability and additive genetic coefficient of variation for optimal and marginal populations. (BHD): diameter at breast height; $(\mathrm{H})$ : height; (CD): crown diameter; (***): $\mathrm{P}<0.0001$; (a): IH (Initial height) is used as covariate and statistically significant for all traits $(\mathrm{P}<0.0001)$; (b): first degree of freedom is for optimal and second is for marginal populations; (c): ranges of traits are in the parenthesis.

\begin{tabular}{lccccccc}
\hline \multirow{2}{*}{$\begin{array}{l}\text { Sources of } \\
\text { variation }\end{array}$} & $\begin{array}{l}\text { Degrees of } \\
\text { freedom }\end{array}$ & \multicolumn{2}{c}{ Optimal Populations } & \multicolumn{5}{c}{ Marginal Populations } \\
\cline { 3 - 8 } & 24 & BHD & H & CD & BHD & H & CD \\
\hline Block & $21.4^{* * *}$ & $23.7^{* * *}$ & $20.9^{* * *}$ & $16.2^{* * *}$ & $16.5^{* * *}$ & $14.1^{* * *}$ \\
Pop & $6-1$ & $2.0^{* * *}$ & $1.0^{* * *}$ & $0.9^{* * *}$ & $6.3^{* * *}$ & $7.1^{* * *}$ & $14.6^{* * *}$ \\
Family(Pop) & $170-37$ & $3.7^{* * *}$ & $5.4^{* * *}$ & $1.8^{* * *}$ & $5.3^{* * *}$ & $3.6^{* * *}$ & $3.4^{* * *}$ \\
Error & $3559-720$ & 72.9 & 69.9 & 76.4 & 72.2 & 72.8 & 67.9 \\
Total & $3903-806$ & 100.0 & 100.0 & 100.0 & 100.0 & 100.0 & 100.0 \\
Mean (c) & - & $23.3(10-57)$ & $244.1(72-421)$ & $163.7(40-315)$ & $17.8(8-48)$ & $248.6(79-381)$ & $141.5(30-260)$ \\
$h_{\mathrm{i}}{ }^{2}$ & - & $0.19 \pm 0.04$ & $0.29 \pm 0.05$ & $0.09 \pm 0.03$ & $0.27 \pm 0.10$ & $0.19 \pm 0.08$ & $0.19 \pm 0.08$ \\
$\mathrm{~V}_{\mathrm{g}}(\%)$ & - & 12.80 & 9.10 & 6.20 & 16.70 & 8.30 & 10.80 \\
\hline
\end{tabular}

group included the seedlings from YATA and BOZD populations, and the optimal group included the other 7 provenances.

Unlike optimal populations, marginal populations showed higher among-population variances compared to family variances. Mean values of breast height diameter, height and crown diameter in optimal group was found higher than those of marginal group. Individual heritability for breast height diameter, height and crown diameter of seedlings were $0.27 \pm 0.10,0.19$ \pm 0.08 and $019 \pm 0.08$ in marginal populations and $0.19 \pm 0.04,0.29 \pm 0.05$ and 0.09 \pm 0.03 in the optimal group (Tab. 4). The additive genetic coefficient of variation for diameter at the breast height was higher than that of other traits for both marginal and optimal populations.

Genetic and phenotypic correlations were slightly higher for the marginal populations than for the optimal ones (Tab. 5). The genetic correlations between breast height diameter and height were high and positive, but for the other trait pairs were low though positive.

\section{Discussion}

In this study, traits likely to be of adaptive importance, such as breast height diameter, height and crown diameter, were analyzed in 5-year-old seedlings of Liquidambar orientalis grown in a common garden experiment. Such traits may be relevant in the competition for light and other resources in forest trees. Vitasse et al. (2009) emphasized that under favorable conditions, a higher growth rate increases species' competitive ability, survival, and long-

Tab. 5 - Genetic (below diagonal) and phenotypic (above diagonal) correlations. (BHD): diameter at breast height; $(\mathrm{H})$ : height; (CD): crown diameter.

\begin{tabular}{lcccccc}
\hline \multirow{2}{*}{ Traits } & \multicolumn{3}{c}{ Optimal Populations } & \multicolumn{3}{c}{ Marginal Populations } \\
\cline { 2 - 7 } & BHD & H & CD & BHD & H & CD \\
\hline BHD & - & 0.74 & 0.48 & - & 0.70 & 0.51 \\
H & $0.83 \pm 0.04$ & - & 0.45 & $1.00 \pm 0.00$ & - & 0.52 \\
CD & $0.45 \pm 0.15$ & $0.55 \pm 0.08$ & - & $0.52 \pm 0.20$ & $0.60 \pm 0.19$ & - \\
\hline
\end{tabular}

3-4 times higher than the family variances for all the traits of the pooled data across populations. The same trend existed also in marginal populations. Velioglu et al. (2008) found a low gene flow coefficient between populations (number of migrants $\mathrm{Nm}=$ 0.42 ) and a high genetic divergence among populations (genetic distance $G_{S T}=0.54$ ). Not only the pooled data across all populations but also findings of the marginal populations supported Velioglu et al. (2008) on the population differentiation. Unlike marginal populations, the family variances in optimal provenances were about 2-5 higher than among-populations variances. Baliuckas et al. (2000) suggest that a large additive variance within populations for adaptive traits is the best assurance for future adaptation. On the other hand, Jensen \& Hansen (2008) suggested that the larger among-population variation (compared to that of families) observed in Quercus robur and Q. petrea reflects a strong adaptation to local sites. Therefore, in the light of the above considerations, both optimal and marginal population groups are functional in maintaining the adaptability of oriental sweetgum to future changes.

Individual heritabilities (0.11-0.27) of pooled data across all populations were in accordance with Cornelius (1994) who reviewed heritabilities of 67 forest tree species and recorded a range of 0.1-0.3. A similar trend was observed for the heritabilities of optimal and marginal populations (0.090.29). Moreover, heritabilities for optimal populations were more similar to those calculated from pooled data than those of marginal populations. Thus, marginal and optimal populations were different in terms of heritability. While breast height diameter and crown diameter were more heritable for marginal populations, height was more heritable for optimal populations. On the other hand, all heritability values estimated in this study could be biased as obtained from a single trial experiment (White et al. 2007). In this context, considering a possible overestimation of heritability, oriental sweet gum exhibited heritability values similar to those observed for 
other forest trees when all populations were studied together, though those values were different when marginal and optimal populations were analyzed separately. Especially, heritability of crown diameter in marginal populations was two times higher than that of optimal populations.

The additive genetic coefficient of variation in breast height was the highest, when compared to that estimated for the other traits, in both the marginal and optimal populations. Cornelius (1994) reported that the additive genetic coefficient of variation in forest trees was less than $15 \%$ on average. The additive genetic coefficient of variation is a good indicator of long-term evolution of a trait and suggests that the studied populations have a good potential for adaptation under changing environmental conditions (Houle 1992, Eriksson et al. 2003, Whiteley et al. 2003, Baliuckas et al. 2005). In this context, breast height diameter in oriental sweet gum might be considered a more plastic trait. On the other hand, the genetic coefficient of variation for the crown diameter in marginal populations was higher than that estimated for optimal provenances. While the mean crown diameter of seedlings from optimal populations ranged from $159.8 \mathrm{~cm}$ to $171.5 \mathrm{~cm}$, mean crown diameter in YATA (the northernmost population) was 150.7 $\mathrm{cm}$ and $128.4 \mathrm{~cm}$ in BOZD (at the highest elevation population - Tab. 2). Because of the narrowest crown diameter recorded in BOZD population, it could be hypothesized that the crown diameter might be related to adaptation of the species to harsh environmental conditions like snow.

The genetic correlation in marginal populations was slightly higher than the genetic correlations in optimal populations. Genetic correlations of breast height diameter and height were high and positive as reported for most forest trees. This suggests that same sets of genes regulate the height and the breast height diameter traits for both marginal and optimal populations (Eriksson et al. 2003).

Oriental sweet gum is one of the 110 species determined by EUFORGEN to be the subject of studies related to genetic conservation (Alan \& Kaya 2003, EUFORGEN 2016). Our findings on oriental sweet gum populations can be evaluated from the perspective of genetic conservation of forest genetic resources under the current climate change. The latest projections indicate that summer temperatures (June-August) will increase by $3-4^{\circ} \mathrm{C}$ in most parts of Europe by 2081 to 2100 , and even $4-5{ }^{\circ} \mathrm{C}$ in some Mediterranean regions (IPCC 2013) where the oriental sweet gum is distributed. The effects of climate change on forest genetic resources will mostly depend on the size and the distribution of the current tree populations and on the biology of the species. A widespread species is expected to be less threatened by the impacts of climate change in comparison to a species with a narrow distribution and small populations (Kelleher et al. 2015). On the other hand, Kreyling et al. (2014) emphasized on local adaptations to environmental conditions and suggested that the increased environmental stress (warming, extreme drought) due to climate change, in combination with the decrease of genetic mixing due to isolation, may lead to stronger local adaptations in geographically marginal populations. Kelleher et al. (2015) suggested two predictions on climate change and forest gene resources which refer also to the oriental sweet gum. The first prediction was that "southern species will face increasing population fragmentation and reduction in population numbers. Some of the southernmost populations are likely to become extinct, resulting in an overall reduction in forest genetic resources." The second was: "within the core of the distribution the most likely outcome will be a change in the species composition through changes in forest dynamics with a possible reduction in genetic diversity". Conversion to farm and settlement pressure (tourism, road building, etc.) were the reasons for fragmentation of oriental sweet gum. As a result of these threats, its distribution area decreased by about a half (Alan \& Kaya 2003). In the existing conditions, optimal populations are expected to be subject to fragmentation resulting from land conversion to farms, building roads etc. Regarding the first prediction by Kelleher et al. (2015), optimal populations should be protected against fragmentation. In this context, at least some of the optimal populations which are far away from human settlements can be designated as in situ genetic conservation units. On the other hand, researches of assisted migration on oriental sweet gum can be carried out to mitigate the second prediction of Kelleher et al. (2015). Marginal populations have shown differentiation, but their genetic plasticity (in terms of additive genetic coefficient of variation) was similar to the optimal ones. Richter et al. (2012) stated that autochthonous provenances of Pinus sylvestris L. had the potential for resistance to changes in climatic conditions as a function of both phenotypic plasticity and genotypic variation. Regarding the European perspective on genetic conservation, the marginal populations of oriental sweet gum may be also thought as an integral part of a strategy for the conservation of its adaptability and evolutionary potential to face the current climate change.

This study has analyzed nine populations of oriental sweet gum, of which two from marginal and seven from optimal sites for the species. As a consequence, standard errors of heritability and genetic correlation in the marginal group were higher than in the optimal group of populations. For this reason, the estimation of genetic parameters for marginal populations should be confirmed using larger datasets. Moreover, heritability was assessed on young seedlings (5-year-old) and therefore predictions of expressed genetic variation in adult trees must be taken with caution. Finally, several common garden experiments established at different localities are needed to assess genotype-environment interactions and confirm the conclusions of this study. Nonetheless, as no previous studies on quantitative traits for oriental sweet gum do exists, the results from marginal and optimal groups are thought to supply an adequate information for the genetic conservation of the species.

\section{Conclusions}

Known patterns of genetic variation among populations are useful in gene resource management as a guide for seed transfer and genetic conservation. In fragmented habitats, opportunities for migration are limited and the conservation of evolutionary potential as a basis for facing environmental change is likely to become especially important. Significant differences were found for each trait among populations of oriental sweet gum. In pooled data across populations and marginal populations, among-population variation was higher than within-population variation for all the traits. Regarding marginal populations, the large between-population variation may also reflect a strong adaptation to local sites, which justify a high conservation priority and the establishment of in situ gene conservation units. On the other hand, the family variances were substantially higher than populations variances in provenances from optimal sites, which provide a good prospect for coping with changed environmental conditions. The ongoing deforestation rate in the optimal distribution area of the species, mainly due to the conversion of natural stands to farmlands, calls for urgent conservation actions for the remnant forest genetic resources.

The presence of additive genetic variation for adaptive traits is important for populations to adapt to a changing environment. The pattern of heritabilities and the genetic coefficients of variations were different, but the pattern of genetic correlations was alike between marginal and optimal populations. The breast height diameter might be the most plastic trait in oriental sweet gum as revealed by highest genetic coefficients of variation in both marginal and optimal groups.

The inclusion of oriental sweet gum in EUFORGEN allow to apply the European perspective on gene conservation to the species. Furthermore, assisted migration can be considered for oriental sweet gum to cope with current climate change, but extensive research is needed on this topic.

\section{Acknowledgments}

The research Project on Oriental sweet gum has been carried out by the Forest Tree Seeds and Tree Breeding Research Institute Directorate in Ankara/Turkey since 
2009. The number of the Project is ANKo33 1624/2009-2026.

Many thanks to Ercan Velioglu, Turgay Ezen, Sadi Siklar and Hikmet Öztürk for their valuable contributions.

\section{References}

Aitken SN, Yeaman S, Holliday JA, Wang TL, Curtis-McLane S (2008). Adaptation, migration or extirpation: climate change outcomes for tree populations. Evolutionary Applications 1: 95-111. - doi: 10.1111/j.1752-4571.2007.00013.x

Alan M, Kaya Z (2003). EUFORGEN technical guidelines for genetic conservation and use for oriental sweet gum (Liquidambar orientalis Mill.) International Plant Genetic Resources Institute, Rome, Italy, pp. 6. [online] URL: http:// books.google.com/books?id=jaMMFW8puAMC Albayrak G, Arican E (2009). Determination of similarity among Turkish Sweet Gum (Liquidambar orientalis Mill.) populations using RAPD marker. African Journal of Biotechnology 8: 142-147. [online] URL: http://www.ajol.info/ index.php/ajb/article/download/59753/48033

Baliuckas V, Lagerström T, Eriksson G (2000). Within-population variation in juvenile growth rhythm and growth in Fraxinus excelsior L. and Prunus avium L. Forest Genetics 7 (3): 183-192. [online] URL: http://www.cabdirect.org/cabdi rect/abstract/20013061404

Baliuckas V, Lagerström T, Norell L, Eriksson G (2005). Genetic variation among and within populations in Swedish species of Sorbus aucuparia L. and Prunus padus L. assessed in a nursery trial. Silvae Genetica 54 (1): 1-8. - doi: 10.1515/ sg-2005-0001

Becker WA (1992). Manual of quantitative genetics. Academic Enterprises, Pullman, WA, USA, pp. 191.

Black-Samuelsson S, Whiteley RE, Junzhan G (2003). Growth and leaf morphology response to drought stress in the riparian broadleaved tree, Ulmus laevis (Pall.). Silvae Genetica 52 (56): 292-299. [online] URL: http://www.thuenen. de/media/institute/fg/PDF/Silvae_Genetica/200 3/Vol._52_Heft_5-6/52_5-6_292.pdf

Brussard PF (1984). Geographic patterns and environmental gradients: the central-marginal model in Drosophila revisited. Annual Review of Ecology and Systematics 15: 25-64. - doi: 10.114 6/annurev.es.15.110184.000325

Cornelius J (1994). Heritabilities and additive genetic coefficients of variation in trees. Canadian Journal of Forest Research 24: 372-379. - doi: 10.1139/x94-050

Dieters MJ, White TL, Littell RC, Hodge GR (1995). Application of approximate variances of components and their ratios in genetic test. Theoretical and Applied Genetics 91: 15-24. doi: 10.1007/BFo0220853

Eckert CG, Samis KE, Lougheed SC (2008). Genetic variation across species' geographical ranges: the central-marginal hypothesis and beyond. Molecular Ecology 17: 1170-1188. - doi: 10.1111/j.1365-294X.2007.03659.x

Eriksson G, Black-Samuelsson S, Jensen M, Myking T, Rusanen M, Skrøppa T, Vakkari P, Westergaard $L$ (2003). Genetic variability in two tree species, Acer platanoides L. and Betula pendula Roth, with contrasting life-history traits. Scandinavian Journal of Forest Research 18 (4): 320-
331. - doi: 10.1080/02827580310015422

EUFORGEN (2016). European forest genetic resource programme. Web site. [online] URL: http://www.euforgen.org/species/

Falconer DS, Mackay TFC (1996). Introduction to quantitative genetics. Longman, Harlow, England, pp. 464.

Gaston KJ (2003). The structure and dynamics of geographic ranges. Oxford University Press, Oxford, UK, pp. 280. [online] URL: http:// books.google.com/books?id=zBqpX1ajLFMC

Houle D (1992). Comparing evolvability and variability of quantitative traits. Genetics 130: 195204. [online] URL: http://www.genetics.org/ content/130/1/195.short

IPCC (2013). Climate change 2013: the physical science basis. Contribution of Working Group I to the Fifth Assessment Report of the Intergovernmental Panel on Climate Change (Stocker $\mathrm{TF}$, Qin D, Plattner GK, Tignor M, Allen SK, Boschung J, Nauels A, Xia Y, Bex V, Midgley PM eds). Cambridge University Press, Cambridge, UK, pp. 1535.

Jensen JS, Hansen JK (2008). Geographical variation in phenology of Quercus petraea (Matt.) Liebl and Quercus robur L. oak grown in a greenhouse. Scandinavian Journal of Forest Research 23 (2): 179-188. - doi: 10.1080/028275808 01995331

Kaya Z, Kandemir G, Cengel B, Icgen Y, Velioglu E, Ozdilek A, Or M (2008). Determination of genetic structure of Anatolian sweetgum (Liquidambar orientalis Mill.) at the population and taxonomic levels based on molecular markers and development of in situ conservation strategies. The Scientific and Technical Research Council of Turkey, Agriculture, Forestry and Veterinary Research Grant Committee, Project Final Report Committee, TOVAG -1040156, pp. 45 .

Kelleher CT, De Vries SMG, Baliuckas V, Bozzano M, Frydl J, Gonzalez Goicoechea P, Ivankovic M, Kandemir G, Koskela J, Koziol C, Liesebach $M$, Rudow A, Vietto L, Zhelev Stoyanov $P$ (2015). Approaches to the conservation of forest genetic resources in Europe in the context of climate change. European Forest Genetic Resources Programme - EUFORGEN, Bioversity International, Rome, Italy, pp. 46. [online] URL: http://www.populus.it/pdf/2015_VIETTO_EUFO RGEN_FGR_AND_CLIMATE_CHANGE_WEB.PDF Kreyling J, Buhk C, Backhaus S, Hallinger $M$, Huber G, Huber L, Anke J, Konnert M, Thiel D, Wilmking M, Beierkuhnlein C (2014). Local adaptations to frost in marginal and central populations of the dominant forest tree Fagus sylvatica $\mathrm{L}$. as affected by temperature and extreme drought in common garden experiments. Ecology and Evolution 4 (5): 594-605. - doi: 10.1002/ ece3.971

Lesica P, Allendorf FW (1995). When are peripheral populations valuable for conservation? Conservation Biology 9: 753-760. - doi: 10.1046/ j.1523-1739.1995.09040753.x

Munthali CRY, Chirwa PW, Akinnifesi FK (2012). Genetic variation among and within provenances of Adansonia digitata L. (Baobab) in seed germination and seedling growth from selected natural populations in Malawi. Agroforestry System 86: 419-431. - doi: 10.1007/s104 57-011-9472-6
OGM (2015). Orman Genel Müdürlügü [General Directorate of Forestry]. Web site. [online] URL: http://www.ogm.gov.tr/SitePages/OGM/O GMDefault.aspx

Or M (2007). The phylogenetic analysis of Liquidambar orientalis Mill. varieties by comparing the non-coding trn regions of the chloroplast genome. Master thesis, Middle East Technical University, Ankara, Turkey, pp. 89.

Ozdilek A (2007). Genetic differentiation of Liquidambar orientalis Mill. varieties with respect to matK region of chloroplast genome. Master thesis, Middle East Technical University, Ankara, Turkey, pp. 103.

Ozdilek A, Cengel B, Kandemir G, Tayanc Y, Velioglu E, Kaya Z (2012). Molecular phylogeny of relict-endemic Liquidambar orientalis Mill. based on sequence diversity of chloroplast-encoded matK gene. Plant Systematics and Evolution 298: 337-349. - doi: 10.1007/s00606-011-054 8-6

Pandey M, Rajora OP (2012). Genetic diversity and differentiation of core vs. peripheral populations of Eastern white cedar, Thuja occidentalis (Cupressaceae). American Journal of Botany 99 (4): 690-699. - doi: 10.3732/ajb.1100116 Rehfeldt GE, Tchebakova NM, Parfenova YI, Wykoff WR, Kuzmina NA, Milyutin LI (2002). Intraspecific responses to climate in Pinus sylvestris. Global Change Biology 8 (9): 912-929. doi: 10.1046/j.1365-2486.2002.00516.x

Richter S, Kipfer T, Wohlgemuth T, Guerrero CC, Ghazoul J, Moser B (2012). Phenotypic plasticity facilitates resistance to climate change in a highly variable environment. Oecologia 169: 269-279. - doi: 10.1007/s00442-011-2191-x

Rose L, Leuschner C, Köckemann B, Buschmann $\mathrm{H}$ (2009). Are marginal beech (Fagus sylvatica L.) provenances a source for drought tolerant ecotypes? European Journal of Forest Research 128: 335-343. - doi: 10.1007/s10342-009-0268-4 SAS Institute Inc (2002). SAS/STAT Users' Guide. SAS Institute, Cary, NC, USA, pp. 5121.

Squillace AE (1974). Average genetic correlations among offspring from open-pollinated forest trees. Silvae Genetica 23 (5): 149-156.

Topcuoglu A (1968). Sigla ormanlarinin islahi, bakimi, sigla yagi istihsali ve kiymetlendirilmesi [Reclamation and tending in the forests of oriental sweet gum, oil production, and oil utilization]. Orman Genel Müdürlügü, Teknik Haberler Bülteni, Yil: 7, Sayi: 28: 3-23- [in Turkish]

Vakkari P, Rusanen M, Kärkkäinen K (2009). High genetic differentiation in marginal populations of European white elm (Ulmus laevis). Silva Fennica 43 (2): 185-196. - doi: 10.14214/sf.205

Velioglu E, Kandemir G, Icgen Y, Cengel B, Alan M, Kaya Z (2008). Türkiye'deki sigla (Liquidambar orientalis Mill.) populasyonlarinin genetik yapisinin moleküler belirteçlerle belirlenmesi ve koruma stratejileri gelistirilmesi [Determination of genetic diversity and gene conservation strategies for oriental sweetgum (Liquidambar orientalis Mill.) populations in Turkey by molecular markers]. Orman Agaçlari ve Tohumlari Islah Arastirma Müdürlügü Teknik Bülten No: 20. 43 s., Ankara. [in Turkish with English summary]

Vitasse Y, Delzon S, Bresson CC, Michalet R, Kremer A (2009). Altitudinal differentiation in growth and phenology among populations of 
temperate-zone tree species growing in a common garden. Canadian Journal of Forest Research 39: 1259-1269. - doi: 10.1139/Xo9-054 White TL, Adams WT, Neale DB (2007). Forest Genetics. CABI Publishing, Cambridge, MA,
USA, pp. 682. - doi: 10.1079/978184593285 5.0000

Whiteley RE, Black-Samuelsson S, Jansson G (2003). Within and between population variation in adaptive traits in Ulmus laevis, the Eure- pean White elm. Forest Genetics 10 (4): 309319. [online] URL: http://agris.fao.org/agrissearch/search.do?recordID=SK2005200017 